\title{
沖縄本島の富栄養化湖沼における ピコ植物プランクトン群集の周年変化
}

\author{
平 塚 智 子*n須 田 彰一郎**
}

\section{Annual Changes in the Picoplankton Communities in a Eutrophic Subtropical Pond}

\author{
Tomoko HIRATSUKA ${ }^{*, \pi}$ and Shoichiro SUDA** \\ * Department of Natural Environmental Studies, Graduate School of Frontier Sciences, University of Tokyo, 5-1-5 Kashiwanoha, Kashiwa- \\ city, Chiba 277-8653, Japan \\ * * Chemistry, Biology \& Marine Science, Faculty of Science, University of the Ryukyus, 1 Senbaru, Okinawa 903-0213, Japan
}

\begin{abstract}
Plankton communities and physicochemical factors were investigated to determine annual changes in the picoplankton communities for one year in the eutrophic subtropical Senbaru Pond in Okinawa-jima, Japan. Cyanobacteria dominated in the picoplankton communities throughout the whole year. The cell densities of picoplankton was high $\left(7.52 \times 10^{3}-1.03 \times 10^{7}\right.$ cells $\left.\cdot \mathrm{mL}^{-1}\right)$. The densities showed positive correlations with water temperatures. In particular, the densities increased over 25 degrees. Nutrients were not limiting factors for growth of picoplankton in Senbaru Pond. The values of turbidity were high after the heavy rains because of red soil runoff; however, there were no correlations between the cell densities and the turbidities. It was considered that water temperature rather than nutrients strongly affected the cell density in Senbaru Pond.
\end{abstract}

Keywords: Picoplankton; Subtropical; Hypereutrophic; Water temperature; Nutrients

\section{1.はじめに}

集水性水域である湖沼では，人間活動にともなう湖沼 への栄養塩類, 内分泌攪乱物質に代表される合成化合物 および難分解性溶存有機物などの流入により，媣刻な水 質污濁が世界中で引き起こされている。淡水域の調査研 究や対策が世界中で多く実施されているが，冷帯域や温 帯域での報告が多い一方で，亜熱帯域㧍よび熱帯域での 報告は少ない ${ }^{1,2)}$ 。とくに亜熱帯域および熱帯域に数多 く存在する島嶼内の小型の淡水域においては夕゙ム湖など を除いてほとんど報告がない ${ }^{3)}$

沖縄島中南部に位置する千原池 $\left(26^{\circ} 14^{\prime} 66^{\prime} \mathrm{N}, 127^{\circ}\right.$ $45^{\prime} 55^{\prime}$ E）は, 面積 $20,000 \mathrm{~m}^{2}$, 平均水深 $1.5 \mathrm{~m}$ の人工池 である。沖縄島では，河川の流程延長が短く，河床勾配 が急なことから雨水が短時間で海に流出するという地理 的特性により淡水域が少ない。千原池の周囲は森林に囲 まれており，池とその周辺は鳥類を始めとした多くの生 物の生息地として重要な役割を担っている ${ }^{4,5)}$ 。

先行調査により千原池ではピコ植物プランクトンが優 占することが観察された。富栄養化した水域での植物プ ランクトンの増殖は利水障害をもたらすため, その対応 は世界中で重要課題として認識されている ${ }^{6)}$ 。中でもピ
コ植物プランクトンに関しては, 1980 年代後半に湖沼 生態系においてピコ植物プランクトンが一次生産者とし て大きな役割を占めていることが明らかになった。国 内では, 1989 年に琵琶湖での大増殖が確認されて以降, 多くの水域で出現実態が明らかにされている ${ }^{6,7)}$ 。しか しながら, 沖縄島でのピコ植物プランクトンに関する報 告はない。

そこで本研究では，沖縄島に位置する千原池において ピコ植物プランクトン群集の季節的変動を観測した。季 節的変動を決定する要因を検証するため, 物理化学的要 因と競合者である他の植物プランクトンや捕食者である 動物プランクトンの状況についても調査を実施した。

\section{2. 方法}

\section{1 調査地点}

千原池は中頭郡中城村の南上原莘山原に源を発してお り（Fig. 1 A), 宇地泊川の上流域に位置している（Fig. $1 \mathrm{~B})$ 。宇地泊川は源から住宅地および農地内を通り千原 池へと流入する。池の水位は池の下流域にある流出口か ら余分な水をオーバーフローさせることにより, 最大水 深が $6 \mathrm{~m}$ に保たれている（Fig. 1 C)。水は池を出た後さ らに西流し, 牧港川と合流し東シナ海に流出する。宇地

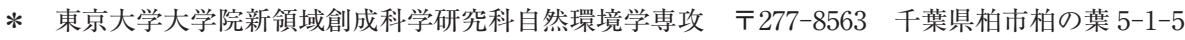

** 琉球大学理学部海洋自然科学科 $\overline{\mathrm{T}} 903-0213$ 沖縄県西原町千原 1 番地

凤 連絡先 : thiratsuka09a@nenv.k.u-tokyo.ac.jp 


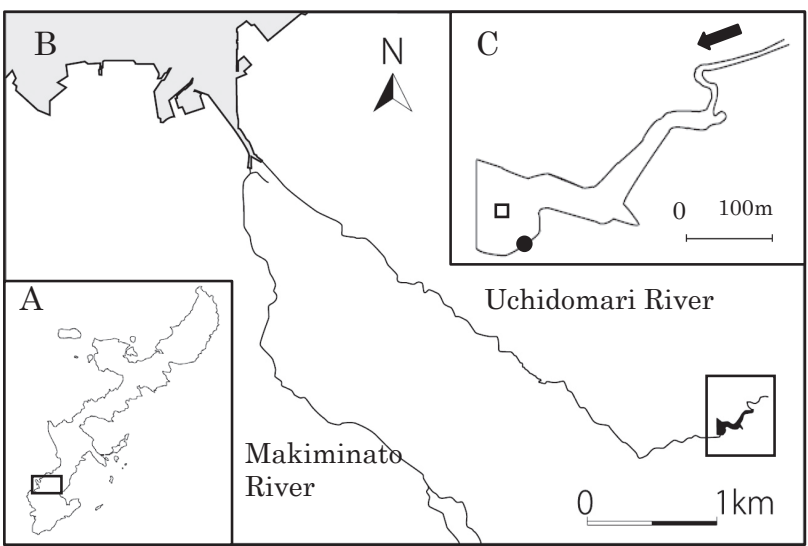

Fig. 1 Map of Okinawa-jima (A), showing the location of Senbaru Pond (B) and the sampled station $(\mathrm{C}, \mathbf{0})$. Pond water runs off from the point $(\mathrm{C}, \square)$. The arrow shows the inflow to the pond $(\mathrm{C})$.

泊川は総延長 $6 \mathrm{~km}$ の二級河川で，水源から東シナ海に 流れ出るまで, 人口が密集する住宅地の中を流れている。

本調查は, 2007 年 11 月 14 日から 2008 年 10 月 28 日 の間実施した。採水は 1 週間から 2 週間ごとに $12: 30$ か ら 14:00の間に行った。調査地点は池の沿岸部に位置し

(Fig. 1 C), 水深は 1.5 $1.8 \mathrm{~m}$ で, 周辺には抽水植物か らなる水生植物群落がある。

\section{2 現場調査方法}

水深は, 錘を備えたメジャーで測定した。水温（WT）, 溶存酸素濃度 (DO), 濁度（Turbidity）は多項目水質 計（WQC-24, TOA-DKK, Tokyo）を用い表層で測定した。 池水はバケツを用いて表層水を採取した後, 䀣濁物質量 （SS）および栄養塩分析用試料として $200 \mathrm{~mL}$, 植物プラ ンクトン観察試料として $1 \mathrm{~L}$ をそれぞれ分取した。植物 プランクトン観察試料は現地においてグルタルアルデヒ ドにより固定した（最終濃度約 $1 \%$ ）。また，試水の一 部は鞭毛虫などの同定の際に遊泳方法や鞭毛の長さ・本 数を確認するため, 固定せずに持ち帰った。動物プラン クトン試料は, 直径 $20 \mathrm{~cm}$ のプランクトンネット（目合 $72 \mu \mathrm{m})$ で表層および中層（1/2 水深）を水平に曳いて 採取し，実験室に持ち帰った。

\section{3 ピコ植物プランクトン細胞数の計数方法}

直径 $2.5 \mathrm{~cm}$ で孔径 $0.1 \mu \mathrm{m}$ のメンブランフィルター (Omnipore, Nihon Millipore K. K., Tokyo) で滤過捕集し た細胞を蛍光装置（D-FL, Nikon, Tokyo）を備えた光学 顕微鏡（Eclips 80i, Nikon, Tokyo）で観察した。G 励起条 件下および $\mathrm{B}$ 励起条件下で観察を行い, 自家蛍光を示 す細胞をそれぞれ計数した。

\section{4 プランクトンの観察方法}

ピコ植物プランクトン以外の動植物プランクトンは, 最初に遊泳方法などの確認のために固定していない試料 を試料採取後 20 分以内に先述の光学顕微鏡を用いて観 察した。固定した試料は, あらかじめ静置し沈殿させ濃 縮したものを観察に供した。上記の試料の観察からでき る限り下位の分類群まで同定した ${ }^{8 \sim 10)}$ 。さらに, 試料を 一定量枠付きスライドガラスに取り無作為に 10 回動か し, 各種のプランクトンが出現する頻度を計測した。同 試料で同様の計測を 10 回行い, 優占種を特定した。

\section{5 水質分析方法}

$\mathrm{SS}$ 測定には乾燥重量法を用いた。天科を用いて秤量 した直径 $45 \mathrm{~mm}$ で粒子保持能 $0.7 \mu \mathrm{m}$ のグラスファイ バー滤紙（GF/F, Whatman, England）を滤過器にセット し試料を一定量取り, 吸引濾過した。滤過後のフィルター を $105^{\circ} \mathrm{C} て ゙ 2$ 時間乾燥し, 真空デシケーター中で放冷し た後, フィルターを天秤で秤量した。濾過前と濾過後の フィルターの重量の差から SS を求めた。

アンモニア態窒素濃度 $\left(\mathrm{NH}_{4}-\mathrm{N}\right)$, 亜硝酸態窒素濃度 $\left(\mathrm{NO}_{2}-\mathrm{N}\right)$, 硝酸態窒素濃度 $\left(\mathrm{NO}_{3}-\mathrm{N}\right)$ およびリン酸態リ ン濃度 $\left(\mathrm{PO}_{4}-\mathrm{P}\right)$ の測定には上記の SS 測定用に濾した滤 液を冷凍保存した後に用いた。 $\mathrm{NH}_{4}-\mathrm{N}$ はインドフェノー ル法, $\mathrm{NO}_{2}-\mathrm{N}$ はナフチルエチレンジアミン法, $\mathrm{NO}_{3}-\mathrm{N}$ はカドミウムカラムで還元して $\mathrm{NO}_{2}-\mathrm{N}$ に変換したのち ナフチルエチレンジアミン法で, $\mathrm{PO}_{4}-\mathrm{P}$ はモリブデン青 法によりオートアナライザー（QuAAtro, Bran+Luebee, Germany）を用いて 1 試料につき各 4 回測定した。窒素 /リン比 (N/P 比) は溶存態無機窒素 DIN $\left(\mathrm{NH}_{4}-\mathrm{N}+\mathrm{NO}_{2}-\right.$ $\left.\mathrm{N}+\mathrm{NO}_{3}-\mathrm{N}\right)$ と溶存態無機リン DIP $\left(\mathrm{PO}_{4}-\mathrm{P}\right)$ を用いて, 重 量比を求めた。

\section{6 解析}

ピコ植物プランクトンの細胞数密度は対数変換後, 水 温, DIN $\left(\mathrm{NH}_{4}-\mathrm{N}+\mathrm{NO}_{2}-\mathrm{N}+\mathrm{NO}_{3}-\mathrm{N}\right), \mathrm{NH}_{4}-\mathrm{N}, \mathrm{NO}_{2}-\mathrm{N}+\mathrm{NO}_{3}-\mathrm{N}$, DIP $\left(\mathrm{PO}_{4}-\mathrm{P}\right)$, 濁度それぞれとの相関関係を求めた。解 析には, Microsoft Excel 2010 （Microsoft, USA）を用いた。 $\mathrm{p}<0.05$ を統計学的に有意な差があると判定した。

\section{3. 結果}

\section{1 物理化学的環境要因}

本調查で得られた水質項目の平均值と変動範囲を Table 1 に示す。本池では, 水温は $15.4 \sim 32.6^{\circ} \mathrm{C}$ の範囲で 推移した (Fig. $2 \mathrm{~A})$ 。溶存酸素は, 1 年を通して過飽和 の状態が多く, 最高值で溶存酸素飽和度 $183 \%$ までに達 した。 $\mathrm{NH}_{4}-\mathrm{N}$ は $0.23 \sim 1.42 \mathrm{mg} \cdot \mathrm{L}^{-1}$ の間で変化し, とくに 11 月から 5 月まで $0.62 \sim 1.42 \mathrm{mg} \cdot \mathrm{L}^{-1}$ の高い濃度で推移 した (Fig. 2 B)。 $\mathrm{NO}_{2}-\mathrm{N}+\mathrm{NO}_{3}-\mathrm{N}$ は $0.48 \sim 2.47 \mathrm{mg} \cdot \mathrm{L}^{-1}$ の 間で変化し, とくに 11 月から 5 月にかけては $1.00 \mathrm{mg} \cdot \mathrm{L}^{-1}$ を上回る高い濃度で推移した（Fig. 2 B)。DIP は 0.01 $\sim 0.27 \mathrm{mg} \cdot \mathrm{L}^{-1}$ の範囲で変化し, 11 月から 4 月までは $0.05 \mathrm{mg} \cdot \mathrm{L}^{-1}$ 以下の低い濃度であったが, 5 月以降から $0.10 \mathrm{mg} \cdot \mathrm{L}^{-1}$ 以上から $0.05 \mathrm{mg} \cdot \mathrm{L}^{-1}$ 以下の範囲で増減が繰 り返し観測された (Fig. 2 C)。調査回数 37 回中 20 回で

Table 1 Means and ranges of physicochemical values in Senbaru Pond during study period (November 2007- October 2008).

\begin{tabular}{ll}
\hline Factors & Mean (range) \\
\hline $\mathrm{WT}\left({ }^{\circ} \mathrm{C}\right)$ & $24.94(15.4-32.6)$ \\
$\mathrm{DO}\left(\mathrm{mg} \cdot \mathrm{L}^{-1}\right)$ & $7.89(3.30-16.63)$ \\
Turbidity $(\mathrm{NTU})$ & $18.3(3.2-99.4)$ \\
$\mathrm{SS}\left(\mathrm{mg} \cdot \mathrm{L}^{-1}\right)$ & $11.8(1.0-70.5)$ \\
$\mathrm{NH}_{4}-\mathrm{N}\left(\mathrm{mg} \cdot \mathrm{L}^{-1}\right)$ & $0.84(0.23-1.42)$ \\
$\mathrm{NO}_{2}-\mathrm{N}+\mathrm{NO}_{3}-\mathrm{N}\left(\mathrm{mg} \cdot \mathrm{L}^{-1}\right)$ & $1.31(0.48-2.47)$ \\
$\mathrm{PO}_{4}-\mathrm{P}\left(\mathrm{mg} \cdot \mathrm{L}^{-1}\right)$ & $0.08(0.01-0.27)$ \\
$\mathrm{N} / \mathrm{P}$ ratio & $38.2\left(3.5^{-97.7)}\right.$ \\
\hline
\end{tabular}


DIP 濃度が 0.04 から $0.10 \mathrm{mg} \cdot \mathrm{L}^{-1}$ の範囲で推移していた。 $0.10 \mathrm{mg} \cdot \mathrm{L}^{-1}$ 以上の值は 7 回観測された。 $\mathrm{N} / \mathrm{P}$ 比 (重量比) は平均 38.2 であり, 3.5〜97.7 の間で変化した。

水の濁りを示す濁度は平均 $18.3 \mathrm{NTU}$ で,3.2 99.4 NTU の間で変化した (Fig. 2 D)。 $\mathrm{SS}$ は平均 $11.8 \mathrm{mg} \cdot \mathrm{L}^{-1}$ で, 1.0 $\sim 70.5 \mathrm{mg} \cdot \mathrm{L}^{-1}$ の間で変化した。調査期間中, 2 月 7 日 (降水量が前日 2 日間で約 $60 \mathrm{~mm}$ ), 6 月 4 日（前日から 採水時までに約 $77 \mathrm{~mm}$ ), 10 月 10 日（前日から採水時 までに約 $110 \mathrm{~mm}$ ）にそれぞれ大雨があった ${ }^{11)}$ 。上記の 採水日には, 池水が表流水による土砂の流入により茶 色く変色し，濁度が52.6，71.1，99.4 NTU， SS が25.0, 46.0, $70.5 \mathrm{mg} \cdot \mathrm{L}^{-1}$ とそれぞれ高い值を示した。沖縄本 島那覇市における調查期間中の降水量の月毎の平年值
は 69.0〜267.5 mm で 4 月に最低值, 9 月に最高值を記 録していた ${ }^{11)}$ 。調査期間中の那覇市における年降水量は $1,790.5 \mathrm{~mm}$ であり, 平年（1971 から 2000 年）に比べゃ や低い值を示した ${ }^{11)}$ 。

\section{2 ピコ植物プランクトン細胞数密度}

本池のピコ植物プランクトンは, 桿状や球状の単細胞 で, 球状の細胞がとくに優占していた。球状の細胞は通 常単細胞で観察されたが, 水温が $25^{\circ} \mathrm{C}$ 以上となる高水 温期には，20〜 50 細胞の群体および偽糸状体を形成し ているものが多数観察された。本池のピコ植物プラン クトンは, G 励起条件下で鮮赤色を示し, B 励起条件下 では自家蛍光が弱い特徵をもつ藍藻類が優占していた。 細胞数密度は, $7.52 \times 10^{3} \sim 1.03 \times 10^{7}$ cells $\cdot \mathrm{mL}^{-1}$ の間で変
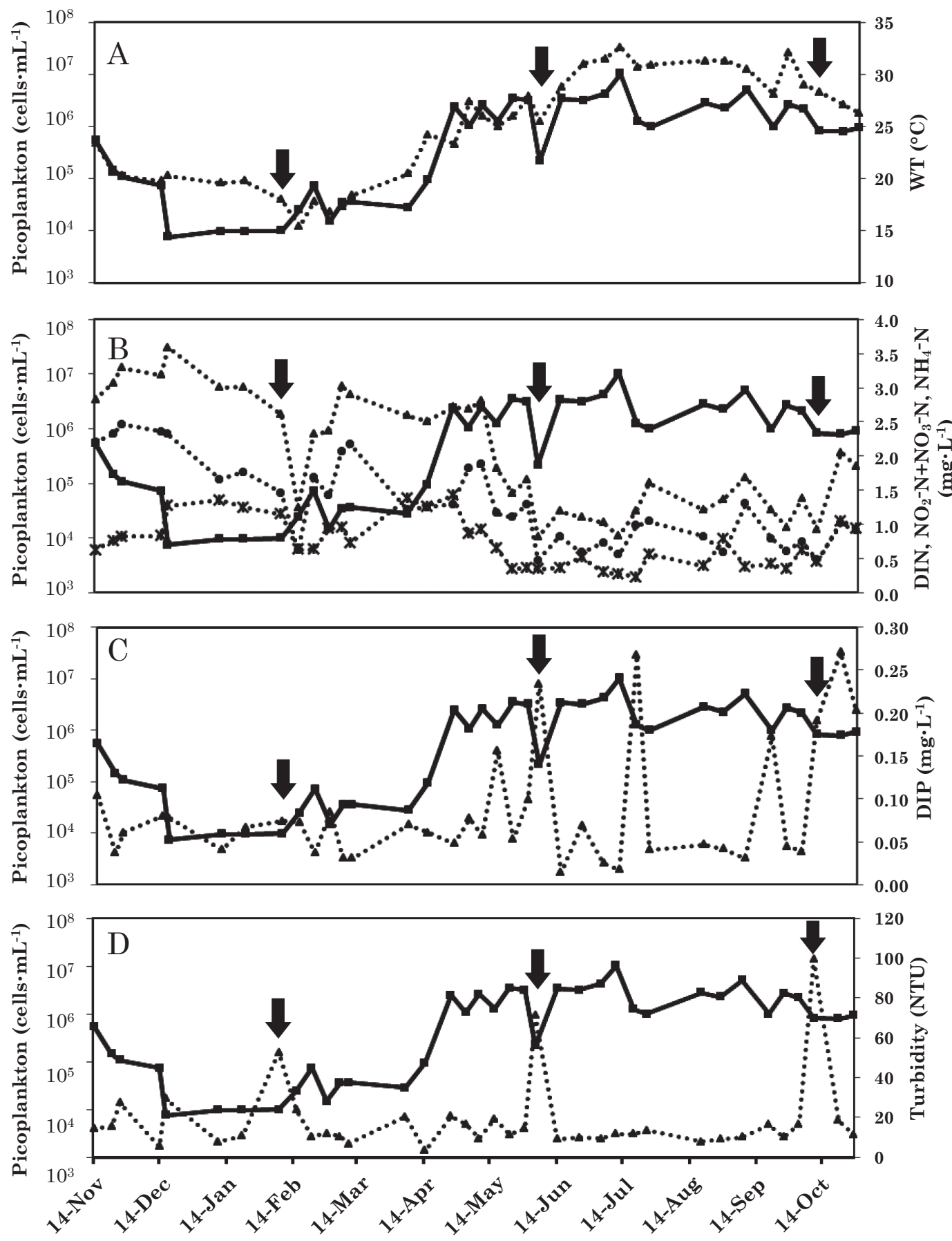

Fig. 2 Annual changes in picoplankton (solid line) and A: WT (dotted line), B: DIN $(\cdots \mathbf{\Delta} \cdots), \mathrm{NH}_{4}-\mathrm{N}(\cdots * \cdots), \mathrm{NO}_{2}-\mathrm{N}+\mathrm{NO}_{3}-\mathrm{N}(\cdots \bullet \cdots), \mathbf{C}: \mathrm{DIP}$ (dotted line), D: Turbidity (dotted line) during study period (November 2007-October 2008). The arrows show the rainy days. 
化し, 平均細胞密度は $1.55 \times 10^{6} \mathrm{cells} \cdot \mathrm{mL}^{-1}$ を示した。と くに 4 月から 10 月の間は $1.0 \times 10^{6} \mathrm{cells} \cdot \mathrm{mL}^{-1}$ 以上の高い 密度を示した。最大出現細胞数は, 7 月 11 日に $1.03 \times$ $10^{7} \mathrm{cells} \cdot \mathrm{mL}^{-1}$ が観察された。12月から 2 月までは $1.0 \times$ $10^{4} \mathrm{cells} \cdot \mathrm{mL}^{-1}$ 未満の低密度で観察され, その後 4 月まで は $1.0 \times 10^{4} \sim 1.0 \times 10^{5} \mathrm{cells} \cdot \mathrm{mL}^{-1}$ の間で変化した。

ピコ植物プランクトンの細胞数密度と水温, DIN $\left(\mathrm{NH}_{4}-\mathrm{N}+\mathrm{NO}_{2}-\mathrm{N}+\mathrm{NO}_{3}-\mathrm{N}\right), \mathrm{NH}_{4}-\mathrm{N}, \mathrm{NO}_{2}-\mathrm{N}+\mathrm{NO}_{3}-\mathrm{N}, \quad \mathrm{DIP}$, 濁度それぞれとの関係を Fig. 2 に示した。ピコ植物プ ランクトンの細胞数密度は, 水温と弱い正の相関を示 した $(r=0.68, \mathrm{p}>0.05)$ 。細胞数密度は水温と同調し て増減していた。水温が $20^{\circ} \mathrm{C}$ 以下のときには $1.0 \times 10^{3}$ $\sim 1.0 \times 10^{4} \mathrm{cells} \cdot \mathrm{mL}^{-1}$ で推移し, $20^{\circ} \mathrm{C}$ から $25^{\circ} \mathrm{C}$ に上がる につれて細胞数密度は増加していた。 $25^{\circ} \mathrm{C}$ 以上で 1.0 $\times 10^{6}$ cells $\cdot \mathrm{mL}^{-1}$ 以上の高い細胞数が観察された。DIN, $\mathrm{NH}_{4}-\mathrm{N}, \mathrm{NO}_{2}-\mathrm{N}+\mathrm{NO}_{3}-\mathrm{N}$ との間に弱い負の相関が認めら れた（順に $\mathrm{r}=-0.55, \mathrm{p}<0.001 ;-0.52, \mathrm{p}<0.01 ;-0.45$, $\mathrm{p}<0.001)$ 。DIP，濁度との間に相関は認められなかった (順に $\mathrm{r}=-0.28, \mathrm{p}<0.05 ; \mathrm{r}=-0.21, \mathrm{p}>0.05) 。$

\section{3 植物プランクトン}

本池では, 出現する植物プランクトン種に明瞭な季 節変化が見られた。5 月から藍藻 Aphanothece sp. が増加 し始め, その後 5 月から 8 月まで最も優占し, 10 月か ら 3 月の間は細胞数が減少した。10月から 4 月にかけ ては鞭毛藻 Mallomonas akrokomos, 鞭毛藻 Cryptomonas tetrapyrenoidosa, 鞭毛藻 Chroomonas sp. が優占した。 上記に挙げた優占種以外では, 緑藻 Chlorella vulgaris, 緑藻 Scenedesmus spp., 緑藻 Sphaerocystis schroeteri, 緑藻 Spermatozopsis aff. exsultans, 珪 藻 Melosira sp., 珪 藻 Cyclotella spp. が周年観察された。

\section{4 動物プランクトン}

動物プランクトンでは季節変化はあまり見られず, 1 年を通して鞭毛虫 Monas spp., 鞭毛虫 Paraphysomonas sp. や繊毛虫 Colpoda sp., 繊毛虫 Paramecium aurelia な どの小型の種が多く観察された。大型の動物プランクト ンである甲殼類は, 出現個体数・種数共に周年少なかっ た。カイアシ類では，ノープリウス期の幼生が 9 月に増 加し，10月以降にはコペポディド期の幼生が増加した。 枝角類では大型の種 $(>1 \mathrm{~mm})$ は観察されず, 比較的 小型の Diaphanosoma sp. や Chydorus sp. がいずれもわず かに出現したのみであった。輪虫類では年間を通して Rotaria sp., Philodina sp. と 2 種の Brachionus spp. が頻繁 に出現した。

\section{4. 考察}

千原池では, ピコ植物プランクトンが高い密度で生 育していた。本池の水質については，1）水温が日本の 池としては周年で $15.4 \sim 32.6^{\circ} \mathrm{C}$ と高い範囲で推移する, 2）過栄養化状態にある，3） N/P 比が平均 38.2 である, 4）大雨後の濁度が高いなどの特徵が見られた。さらに, 植物プランクトンでは藍藻類と鞭毛藻類が優占してお り，動物プランクトンは小型の種が優占していた。これ らの要因がどのように影響して, 千原池のピコ植物プラ ンクトン群集が形成されているかを検討した。

\section{1 物理化学的環境要因}

千原池でのピコ植物プランクトンの最大出現細胞数
は $1.03 \times 10^{7} \mathrm{cells} \cdot \mathrm{mL}^{-1}$ であった。温帯域の淡水湖沼に おける調查では, 最大出現細胞数は $1.0 \times 10^{5} \mathrm{cells} \cdot \mathrm{mL}^{-1}$ 程度であると報告されている ${ }^{12)}$ 。それに対して亜熱帯 域に位置する千原池では, 平均細胞数密度が $1.55 \times$ $10^{6}$ cells $\cdot \mathrm{mL}^{-1}$ を計測しており極めて高い。本研究におけ るピコ植物プランクトン細胞数密度は $25^{\circ} \mathrm{C}$ 以上にまで 水温が達した期間に急激な増加が観察されており, その 結果として両者の間に正の相関が示された (Fig. 2 A)。 一般的に淡水域におけるピコ植物プランクトン群集は 主に藍藻類によって構成されていることが知られてお $\eta^{7.13)}$, 千原池においても同様であった。藍藻類の適温 は $25^{\circ} \mathrm{C}$ 以上であることから ${ }^{12)}, 5$ 月後半から 10 月にか けての高水温期に観察されたピコ植物プランクトンの急 激な増加は水温増加にともなう温度制限の緩和によるも のと説明できる。さらに国内および海外における調査に おいても, ピコ植物プランクトンの最大細胞密度は最大 水温時に観察されていることから ${ }^{13 \sim 16)}$, 両者が密接な 関係にあることが肯定される。

栄養塩類との関係では, ピコ植物プランクトンの細胞 数密度と $\mathrm{NH}_{4}-\mathrm{N}, \mathrm{NO}_{2}-\mathrm{N}+\mathrm{NO}_{3}-\mathrm{N}, \mathrm{DIN}$ との間に弱い負 の相関が認められた。これは 5 月後半から水温が増加 し始めピコ植物プランクトンの増殖が促進されると, 細 胞数密度が増加したことにより窒素が消費され窒素濃度 が減少したためと考えられる。逆に, 水温が低くピコ植 物プランクトンの細胞数密度が抑えられている 11 月か ら 5 月前半までは, 窒素濃度が増加したと推察される。

DIP 濃度は 0.04 から $0.10 \mathrm{mg} \cdot \mathrm{L}^{-1}$ の範囲で大部分が推 移していたが，たびたび $0.10 \mathrm{mg} \cdot \mathrm{L}^{-1}$ 以上の急激なピー クが観察された。淡水域におけるDIP 濃度は外部およ び内部負荷による供給と植物プランクトン群集による消 費によって変動するが, 高濃度のカルシウムイオンが存 在する水域ではDIP はカルシウムイオンと結合して凝 集沈殿するためリン制限が起きやすいことが知られてい る ${ }^{17)}$ 。千原池が位置する沖縄本島中南部は琉球石灰岩地 質からなるため, 池水中のカルシウムイオン濃度は非常 に高く，硬度が 205 410 $\mathrm{mg} \cdot \mathrm{L}^{-1}$ と報告されている ${ }^{18)}$ 。 しかしながら本池では, ピコ植物プランクトンの細胞数 密度とDIPの間に明確な相関関係は確認されなかった

(Fig. 2 C)。これは本池が過栄養状態にあり, ピコ植物 プランクトンの増殖に十分な量のリンが存在しているた めに, リンが制限要因にはならなかったためであると推 察される。また, 藍藻類 Microcystis spp. は高い硬度によ り, 増殖が阻害されるという報告がある ${ }^{19)}$ 。本研究では, 硬度の季節的変動を測定していなかったため, 硬度のピ コ植物プランクトンの細胞数密度に及ぼす影響を明らか にすることができなかったが, 今後の更なる研究を期待 したい。

N/P 比はとくに藍藻類の増殖に関わる重要な環境因子 であることが知られている。N/P 比が 30 を超えると藍 藻類の優占率が低下することが, 国内および海外湖沼で の調査から報告されている ${ }^{12)}$ 。本池では N/P 比の年平均 值が 38.2 を示していたにも関わらず, ピコ植物プラン クトン群集内で藍藻類が優占していた。上記の報告での 湖沼では, リン濃度が低下したために N/P 比が高くなっ ており，そのためにリン濃度が制限要因となって増殖が 抑制されたと推察されていた。千原池では, リン濃度が 
制限要因とはなっていないと考えられ，N/P 比が 30 以 上になる場合が多いにも関わらず藍藻類が優占したと考 えられる。またドイツの湖沼で 30 年間にわたって行わ れた調査によると, 栄養塩類濃度が高いほど N/P 比に 関わらず藍藻類の優占率が増加するとされており ${ }^{20)}$, 本 研究の結果と一致した。

千原池では大雨後に濁度が $50 \mathrm{NTU}$ 以上の高い值を示 した (Fig. 2 D)。沖縄島の降雨の特性は, 降り方がス コール型であり，その雨滴が比較的大きく侵食性の雨が 多( ${ }^{21)}$ 。加えて, 本池の周辺土壤は極微小な赤土土砂で ある島尻マージと国頭マージから成っている ${ }^{4,5)}$ 。これ らの土壤は, 雨水の透水性が悪く表流水が増大するなど の理由で侵食されやすい ${ }^{21)}$ 。本池の周辺の崖地形には森 林が残っているが, 工事により表土がむき出しの状態と なっており，土砂の流出源となっていた。そのため，大 雨の度に沈殿しにくい極微小な赤土土砂粒子が流入河川 から池内へ流入し, 濁度が増大した。細かい粒子である 赤土の流入による植物プランクトンへの影響としては, 濁度増加により光合成が阻害されることや赤土粒子によ りプランクトンの沈降が促進されることなどが挙げられ る。これらの効果によるプランクトン群集への影響は, 海洋域ではすでに多く報告されている ${ }^{21)}$ 。本池でも赤土 流入が確認されたことから，淡水域においても影響が大 きい可能性が示唆された。赤土流入のプランクトン相に 対する影響を適切に評価することは, 島内の淡水域だけ でなく海洋域の保全の面からも有用であるため, 更なる 調査や実験が求められる。

さらに千原池の流入河川は 1 本であり, その流入量は 非常に少ない。そのため, 池内での水の動きは少なく水 の安定性が高い。オランダの過栄養化した水域での調査 によると, 水の安定性の高い水域では, 緑藻類や珪藻類 や鞭毛藻類は藍藻類と比較して, 生存に不利であること が報告されている ${ }^{22)}$ 。水の安定性が高いことと，水温が 藍藻類の増殖に適していたことが，千原池において藍藻 類から構成されるピコ植物プランクトンが高い細胞数密 度で観測された要因であると考えられる。

植物プランクトンの季節的遷移はエネルギー（光量と 水温）と栄養塩類によって引き起こされる。そのため, 温帯域などに比べてエネルギー変動が小さい亜熱帯域で は, 相対的に栄養塩類による影響を強く受けると考えら れている。しかしながら本池では，過栄養化状態にある ことにより，栄養塩類の影響は大きく受けていないこと が分かった。本池では, 栄養塩類よりも水温によってピ コ植物プランクトンの細胞数密度の変化が著しいことが 明らかになった。

\section{2 生物的環境要因}

千原池の植物プランクトン相の傾向としては, 主に藍 藻類で構成されるピコ植物プランクトンが高密度で観察 され，その他には藍藻類 Aphanothece sp. が優占してい た。本池は藍藻類の増殖の適温である $25^{\circ} \mathrm{C}$ 以上になる ことが多く，さらに過栄養化状態にあることから藍藻類 の増殖に適していたことが示唆された。さらに水の安定 性の高い本池に扔いては, 細胞体積の小さな藍藻類やピ コ植物プランクトンの沈降速度が遅いために, 光合成に 際して有利である。中でも, より細胞体積が小さいピコ 植物プランクトンが Aphanothece sp. と比較しても有利
であり，その結果として本池ではピコ植物プランクトン が高密度で存在したと考えられる。

さらにピコ植物プランクトンと藍藻類を除くと鞭毛藻 類が優占していた。ピコ植物プランクトンと鞭毛藻類 は栄養塩類や光の獲得に関して競合関係にある7)。本池 ではピコ植物プランクトンが周年優占していたが, 鞭 毛藻類は 10 月から 4 月に多く観察され, その期間中の ピコ植物プランクトンの細胞数密度は低い值を示した。 10 月から 4 月は水温が比較的低く, $25^{\circ} \mathrm{C}$ 以上の水温が 適温であるピコ植物プランクトンの増殖が制限されてい たと推察される。競合関係にあるピコ植物プランクトン が減少した結果, 鞭毛藻類が増殖したと考えられる。他 の生物群の中で鞭毛藻類が優占した理由としては, 水の 安定性の高い千原池で光合成をするためには遊泳力のあ る種が有利であったためと推察される。

動物プランクトン群集では周年小型の繊毛虫類・鞭毛 虫類・輪虫類が優占していた。これらの生物群は, ピコ 植物プランクトンを捕食する ${ }^{7)}$ 。本池ではピコ植物プラ ンクトンが年間を通して高密度で存在していたために, ピコ植物プランクトンを慨資源とする種が優占したと考 えられる。しかしながら, 動物プランクトン群集に関し ては周年多く観察されなかったことから, 動物プランク トン群集はピコ植物プランクトンの季節的変動に大きな 影響は及ぼしていなかったと推察される。

\section{5. まとめ}

2007 年 11 月から 2008 年 10 月にかけて, 沖縄島中南 部に位置する千原池においてピコ植物プランクトンの季 節的変動を観測し，以下のことが明らかになった。

1）千原池のピコ植物プランクトンは藍藻類が優占して おり, 細胞数密度は水温と正の相関を示した。さらに 最高出現細胞数が $1.03 \times 10^{7} \mathrm{cells} \cdot \mathrm{mL}^{-1}$ に達するなど, 温帯域に位置する他の富栄養化湖沼と比較して高い密 度を示した。とくに水温が $25^{\circ} \mathrm{C}$ 以上で高い細胞数密 度が観察された。

2）千原池は窒素とリンが豊富に存在する過栄養化状態 にあるため, 栄養塩類はピコ植物プランクトンの増殖 の制限要因とはなっていないことが示唆された。

3）千原池では大雨後に赤土粒子が流入することにより 高い濁度值を示したが, ピコ植物プランクトンの細胞 数密度との相関関係は認められなかった。

\section{謝 辞}

研究に際して, 多くの助言をいただきました東京大学 の山室真澄教授と広島大学の加藤亜記氏に深くお礼申し あげます。測定機器の使用に快くご協力いただいた三村 泉美氏に厚くお礼申しあげます。また，查読者からは有 益な助言を数多くいただきました。ここに深く感謝の意 を表します。

（原稿受付 2010 年 6 月 24 日) （原稿受理 2011 年 4 月 22 日)

\section{参 考 文 献}

1 ) Havens, K. E., Beaver, J. E. and East, T. L. (2007) Plankton biomass partitioning in a eutrophic subtropical lake: comparison with results from temperate lake ecosystems, Journal of Plankton Research, 29 (12), 1087-1097. 
2) Jeppesen, E., Meerhoff, M., Jacobsen, B. A., Hansen, R. S., Søndergaard, M., Jensen, J. P., Lauridsen, T. L., Mazzeo, N. and Branco, C. W. C. (2007) Restoration of shallow lakes by nutrient control and biomanupilation-the successful strategy varies with lake size and climate, Hydrobiologia, 581, 269-285.

3 ) 川上達也 (2002) 沖縄島福地ダム湖における淡水プランクトン 相, Biol.Mag. Okinawa, 40, 63-91.

4 ）清水肇, 山里勝己, 浜崎盛康, 赤嶺政信, 仲間勇栄, 前門晃, 佐々 木健志, 伊澤雅子, 立原一憲, 新里孝和, 渡久山章 (2002)「琉球 大学を含む水系・流域群における水環境の改善のための総合調 査」2002年度研究報告書, 54pp., 琉球大学, 沖縄.

5 ） 清水肇, 山里勝己, 浜崎盛康, 仲間勇栄, 前門晃, 廣瀬孝, 佐々 木健志, 伊澤雅子, 新里孝和, 立原一憲, 須田彰一郎, 渡久山章, 神谷大介 (2005)「琉球大学を含む水系・流域群に扮ける水環境 の改善のための総合調査」研究報告書 (2002年度〜2004年度), 104pp., 琉球大学, 沖縄.

6 ) Maeda, H., Kawai, A. and Tilzer, M. M. (1992) The water bloom of Cyanobacterial picoplankton in Lake Biwa, Japan, Hydobiologia, 248, 93-103.

7 ) Stockner, J., Callieri, C. and Cronberg, G. (2002) Picoplankton and Other Non-Bloom-Forming Cyanobacteria in Lakes in "The Ecology of Cyanobacteria: Their Diversity in Time and Space” (Whitton, B. A. \& Potts, M.), pp.195-224., New York Kluwer Academic Publishers, New York.

8 ） 水野壽彦 (1964) 日本淡水プランクトン眓鑑, pp.351., 保育社, 大阪.

9 ) 水野壽彦, 高橋永治 (2000) 日本淡水動物プランクトン検索図 説, 551pp., 東海大学出版会, 東京.

10）月井雄二 (1995) 原生生物情報サーバ, http://protist.i.hosei.ac.jp/ protist_menu.html (2010 年 8 月時点).

11）気象庁, 過去の気象デー夕検索 (沖縄県那覇市) 月ごとの值, http://www.data.jma.go.jp/obd/stats/etrn/view/monthly_s1.php?prec_ no $=91 \&$ prec_ch $=\% 89 \%$ AB $\% 93 \%$ EA $\% 8 C \%$ A 8 \&block_no $=$ 47936\&block_ch $=\% 93 \%$ DF\%94e\&year $=2007 \&$ month $=11 \&$ day $=$ \&elm $=$ monthly\&view $=(2010$ 年 8 月現在 $)$.

12）藤本尚志, 福島武彦, 稲森悠平, 須藤隆一 (1995) 全国湖沼デー
夕の解析による藍藻類の優占化と環境因子との関係, 水環境学 会誌, 18 (11), 901-908.

13）一柳淳一, 千葉信男, 後藤光亀, 須藤隆一 (1997) 水源眝水池に おける植物プランクトンの出現実態, 水環境学会誌, 20 (1), 29-35.

14) Stenuite, S., Tarbe, A.-L., Sarmento, H., Unrein, F., Pirlot, S., Sinyinza, D., Thill, S., Lecomte, M., Leporcq, B., Gasol, J., M. and Descy, J.-P. (2009) Photosynthetic picoplankton in Lake Tanganyika: biomass distribution patterns with depth, seston and basin, Journal of Plankton Research, 31 (12), 1531-1544.

15) Chen, M., Chen, F., Zhao, B., Wu, Q. L. and Kong F. (2010) Seasonal variation of microbial eukaryotic community composition in the large, shallow, subtropical Taihu Lake, China, Aquat Ecol, 44, $1-12$.

16) Kruk, C., Rodríguez-Gallego, L., Meerhoff, M., Quintans, F., Lacerot, G., Mazzeo, N., Scasso, F., Paggi, J. C., Peeters, E. T. H. M. and Martin, S. (2009) Determinants of biodiversity in subtropical shallow lakes (Atlantic coast, Uruguay), Freshwater Biology, 54, 2628-2641.

17) Sierp, M. T. and Qin, J. G. (2001) Effects of fertilizer and crayfish on plankton and nutrient dynamics in hardwater ponds, Hydrobiologia, 462, 1-7.

18）渡久山章 (2005) 宜野湾市宇地泊川の浄化に向けて. 清水肇 (編), 「琉球大学を含む水系・流域群における水環境の改善のた めの総合調査」研究報告書 (2002年度 2004 年度), pp.74-84., 琉 球大学, 沖縄.

19) Wu, J.-T. and Kow, L.-C. (2010) Alteration of phytoplankton assemblages caused by changes in water hardness in Feitsui Reservoir, Taiwan, Botanical Studies, 51, 521-529.

20) Wagner, C. and Adrian, R. (2009) Cyanobacteria dominance, Quantifying the effects of climate change, Limnol. Oceanogr., 54 (6, part2), 2460-2468.

21）大見謝辰男（1995）赤土污染とサンゴ礁, みどりいし，6，7-9.

22) Visser, P. M., Ibelings, B. W., Veer, B. V. D., Koedood, J. and Mur, L. R. (1996) Artificial mixing prevents nuisance blooms of the cyanobacterium Microcystis in Lake Nieuwe Meer, the Neterlands, Freshwater Biology, 36, 435-450.

\section{[論 文 要 旨 $]$}

沖縄県中南部に位置する富栄養化湖沼の千原池において, ピコ植物プランクトンの細胞数密度の季節的変 動を周年観測し, 物理化学的環境要因と生物的環境要因からピコ植物プランクトンの変動要因を明らかにし た。千原池のピコ植物プランクトン群集内では藍藻類が優占し, 細胞数密度が高い值で検出された（7.52× $\left.10^{3} \sim 1.03 \times 10^{7} \mathrm{cells} \cdot \mathrm{mL}^{-1}\right)$ 。物理化学的環境要因との関係から, 細胞数密度は水温と弱い正の相関が見られた。 とくに水温が $25^{\circ} \mathrm{C}$ 以上で高い密度が観察された。栄養塩類との関係から, 本池のピコ植物プランクトンの 細胞数密度の増殖に栄養塩類は制限要素となっていないことが分かった。さらに大雨後には赤土の流入によ り濁度が高い值を示していたが, 細胞数密度との相関関係は認められなかった。本池では栄養塩類よりも水 温がピコ植物プランクトンの細胞数の変動に強く影響を及ぼしていることが明らかになった。

\section{キーワード：ピコ植物プランクトン；亜熱帯；過栄養化；水温；栄養塩類}

